\title{
Optimum condition of biodiesel production from waste cooking oil using continuous stirred tank reactor
}

\author{
Erna Astuti, Zahrul Mufrodi \\ Department of Chemical Engineering, Faculty of Industrial Technology, Universitas Ahmad Dahlan \\ Jl. Prof. Dr. Soepomo, S.H.Janturan Yogyakarta 55164 Indonesia
}

\begin{abstract}
Energy demand in Indonesia is increasing, but the availability of fossil energy is running low. Therefore the effort to get renewable energy is increasingly encouraged. The most widely alternative energy used in Indonesia is biodiesel. Waste cooking oil is very potential to be utilized as raw material of biodiesel. Currently there are 3.75 million liters of waste cooking oil per year. Waste cooking oil when discharged into the body of water will form a layer so that oxygen is blocked into the water. Utilization of waste cooking oil into biodiesel will reduce the burden of environmental pollution by waste cooking oil. This paper proposes optimum conditions of biodiesel production from waste cooking oil using continuous stirred tank reactor with base catalyst. The research variables are reaction temperature, the mole ratio of waste cooking oil and methanol, and the amount of catalyst. This paper also evaluates the heating value of biodiesel produced from waste cooking oil.
\end{abstract}

Keywords: Biodiesel, waste cooking oil, continuous stirred tank reactor, quality standard

\section{Introduction}

Biodiesel is one of the most promising renewable energies [1,2] and is produced from various vegetable oils such as palm oil, coconut oil, jatropha oil, kapok seed oil, animal fats and waste cooking oil[3-6]. Vegetable oils that are prospective for biodiesel feedstock are palm oil and its derivatives. But palm oil has some disadvantages between being easily oxidized and being damaged because palm oil contains lots of fatty acids. The use of palm oil will disrupt the availability of palm oil as cooking oil so as to interfere with food security [7]. In addition, biodiesel production from vegetable oil is higher than fossil oil due to high raw material cost. One alternative to get biodiesel at low cost is to use the raw material of waste cooking oil [8]. Ruhyat and Firdaus [9] evaluated the feasibility of some biodiesel raw materials and stated that the most suitable vegetable oils are used as biodiesel raw materials is waste cooking oil. The processing of biodiesel from waste cooking oil is an effective way to reduce the selling price of biodiesel due to the low cost of raw materials [10].

Palm oil is one of the most widely produced oil in the world and Indonesia is the largest producer of palm oil in the world. Data from the Ministry of Agriculture stated that Indonesia's palm oil production in 2016 is 32 million tons, 27 tons are exported and 5 million is used for domestic consumption. If there is a $25 \%$ shrinkage during frying, there will be 3.75 million tons of waste of waste cooking oil. Utilization of waste cooking oil into biodiesel is one effort to overcome the waste cooking oil as well as become one of renewable alternative energy sources.

The transesterification process can be done in batch or continuous. Transesterification reactions can be done using three kinds of catalyzed so this reaction can be divided as acid catalyzed reactions [11], alkaline catalyzed reactions [12], or enzyme catalyzed reactions [13]. Processes that use enzymes as catalysts require a much longer reaction time than other processes. Therefore, this process is rarely

\footnotetext{
* Manuscript received July 13, 2018; revised January 12, 2019.

Corresponding author. E-mail address: erna.uad@che.uad.ac.id.

doi: 10.12720 /sgce.8.2.201-205
} 
studied and used. In this study continuous transesterification reaction of waste cooking oil with variations in comparison of waste cooking oil and methanol with $\mathrm{KOH}$ catalyst.

\section{Methodology}

The materials used were waste cooking oil from household waste with a mass density of $0.99 \mathrm{~g} / \mathrm{ml}$, methanol with a mass density of $0.792 \mathrm{~g} / \mathrm{ml}$ and free fatty acid of 1.43, and kalium hydroxide (KOH) from Merck.

Waste cooking oil, which was heated at $60{ }^{\circ} \mathrm{C}$, and methoxide solution was continuously streamed into continuously stirred tank reactor with a ratio of waste cooking oil and methanol of 1:4, 1: 6, 1: 8 and 1:10. The residence time was 1.5 hours. The product of the transesterification reaction was flowed continuously to the container. After the process is complete, the solution was to stay overnight. Furthermore, the separation of biodiesel and glycerol results was done. Then the quality of biodiesel were analysis refer to ASTM methods.

\section{Result and Discussion}

Waste cooking oil is very potential to be utilized as raw material for producing biodiesel because it contains enough fatty acids. To prove the presence of fatty acids in biodiesel made from waste cooking oil, sample was analyzed by gas chromatography mass spectrometry (GCMS). The result of GCMS analysis of biodiesel is:

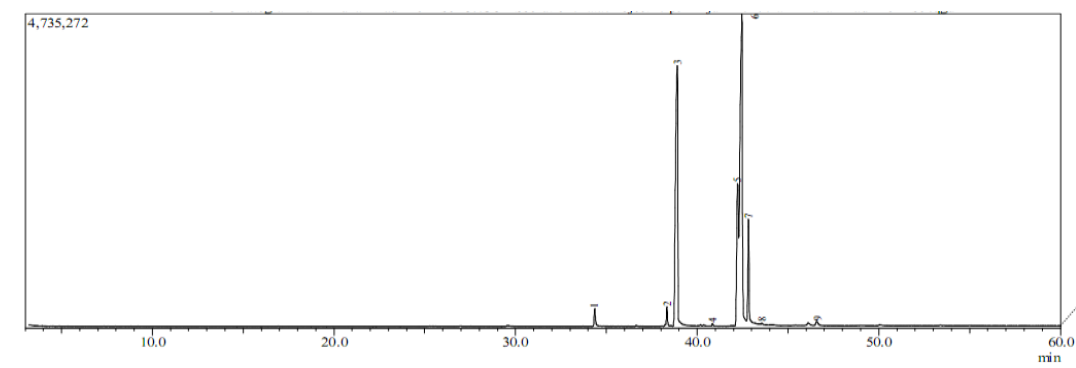

Fig. 1. The GCMS analysis of biodiesel from waste cooking oil at temperature of $60{ }^{\circ} \mathrm{C}$, mole ratio of oil/methanol of $1: 6$ and the amount of $\mathrm{KOH}$ catalyst of $1.5 \% \mathrm{~b} / \mathrm{b}$ of waste cooking oil.

Fig. 1 shows that the biodiesel consists of several kinds of compounds, as evidenced by the presence of several peak areas in the reading. The compounds are within the range of retention time of 34 minutes to 47 minutes.

The type of fatty acid formed in the biodiesel production reaction depends on the type of vegetable oil used as the raw material and the treatment performed. Taufiqurrahmi et al [14] stated that biodiesel from cooking oil consists of palmitic acid, stearate acid, oleic acid, linoleic acid, linolenic acid, palmitic acid, lauric acid and other acidic species. In this study, biodiesel, which was produced contain several fatty acids, shown in Table 1.

Table 1. Types of fatty acids in biodiesel from waste cooking oil

\begin{tabular}{lcr}
\hline \multicolumn{1}{c}{ Compound } & Mass weight, g/gmol & $\% \mathrm{~b} / \mathrm{b}$ \\
\hline 9-Hexadecenoic acid & 268 & 1,29 \\
Pentadecanoic acid & 270 & 35,10 \\
9,12-Octadecadienoic acid & 294 & 14,38 \\
11-Octadecenoic acid & 296 & 0,06 \\
Octadecanoic acid & 298 & 48,71 \\
Eicosanoic acid & 326 & 0,46 \\
\hline Total & & 100,0 \\
\hline
\end{tabular}


Table 1 shows fatty acids formed from transesterification reactions are fatty acids with a carbon number ranging from 17 to 19 . The type of fatty acids present in large quantity is octadecanoic acid. From table 1 we can calculate molecular weight of biodiesel, which is equal to $287.34 \mathrm{~g} / \mathrm{gmol}$.

This research has studied the effect of reaction temperature, mole ratio of waste cooking oil/methanol and the amount of catalyst. The previous paper [15] determined that biodiesel, which on specification of Indonesian biodiesel quality standards was biodiesel produced at mole ratio of oil/methanol of $1 / 6$. This paper discusses the optimum condition of biodiesel production uses waste cooking oil, especially the reaction temperature and the amount of $\mathrm{KOH}$ catalyst. The yields of biodiesel in different temperature are listed in Table 2.

Table 2. Yield of biodiesel (mole ratio of oil/methanol of $1 / 10, \mathrm{KOH}$ of $1 \% \mathrm{~b} / \mathrm{b}$ )

\begin{tabular}{cc}
\hline Reaction temperature, ${ }^{\circ} \mathrm{C}$ & yield of biodiesel, \% v/v \\
\hline 55 & 43,4 \\
60 & 64,8 \\
65 & 61,2 \\
\hline
\end{tabular}

Table 2 explains that the maximum yield of biodiesel was obtained at reaction temperature of $60{ }^{\circ} \mathrm{C}$. At temperature of $65{ }^{\circ} \mathrm{C}$, the yield of biodiesel decrease. Probably on this condition a part of the methanol vapored because the boiling point of methanol is $64,7{ }^{\circ} \mathrm{C}$.

Trans-esterification commonly use acid catalyst $\left(\mathrm{HCl}, \mathrm{H}_{2} \mathrm{SO}_{4}\right)$ or base catalyst $\left(\mathrm{NaOCH}_{3}, \mathrm{KOH}\right.$, $\mathrm{NaOH}$ ). The most commonly used base catalyst is $\mathrm{NaOH}$ or $\mathrm{KOH}$ of 0.5 to $1.0 \%$ by weight of oil [16]. The $\mathrm{KOH}$ is more reactive than $\mathrm{NaOH}$, so the conversion obtained with a $\mathrm{KOH}$ catalyst is higher than that of $\mathrm{NaOH}$. Because of this reason, this research used $\mathrm{KOH}$ as a catalyst. The amount of catalyst (percentage of the weight of waste cooking oil) was varied. The yield of biodiesel can be read in Table 3 .

Table 3. Yield of biodiesel (at mole ratio of oil/methanol of 1/10, temperature of $60 \mathrm{oC}$ )

\begin{tabular}{cc}
\hline Amount of catalyst, \% & Yield of biodiesel, \% \\
\hline 1.0 & 68.90 \\
1.5 & 63.54 \\
2.0 & 86.44 \\
2.5 & 61.07 \\
3.0 & 61.94 \\
\hline
\end{tabular}

Table 3 described that the optimum amount of $\mathrm{KOH}$ catalyst is $2.0 \% \mathrm{~b} / \mathrm{b}$ of waste cooking oil. At above percentage, the using of catalyst cause side reaction, probably the saponification was conducted. The side reaction cause the yield of biodiesel decrease.

To know the potential usage of this research, this paper also evaluate heating value of biodiesel from waste cooking oil (see Table 4).

Table 4. Heating value of biodiesel

\begin{tabular}{cc}
\hline Ratio of oil/methanol & Heating value, Cal/kg \\
\hline $1: 4$ & 9580.568 \\
$1: 6$ & 9679.308 \\
$1: 8$ & 9842.613 \\
$1: 10$ & 9527.875 \\
\hline
\end{tabular}


The heating value of fuel oil, include diesel, is in the range from 18,300 to $19,800 \mathrm{Btu} / \mathrm{lb}$ [17]. National standard of Indonesia gives the rule that the minimum heating value of biodiesel is 8,843.22 Cal $/ \mathrm{kg}$ [15]. The average heating value of biodiesel produced is $9,657.591 \mathrm{Cal} / \mathrm{kg}$. This proves that the biodiesel from waste cooking oil can replace the function of diesel as fuel. Biodiesel from waste cooking oil can be used as alternative energy. The data presented in this paper can be used as biodiesel plant design data from waste cooking oil. Furthermore, glycerol as by-product biodiesel is also utilized into products that have more value-added such as triacetin [18,19] and 1,3-dinitroglycerin [20,21]. This will increase the economic value of the biodiesel plant from used cooking oil.

\section{Conclusion}

Biodiesel produced $100 \%$ contains fatty acids and consists of various fatty acids. Optimum conditions of production biodiesel from waste cooking oil are mole ratio of waste cooking oil/methanol of $1 / 6$, the reaction temperature of $65^{\circ} \mathrm{C}$ and the amount of $\mathrm{KOH}$ catalyst of $2 \% \mathrm{~b} / \mathrm{b}$ of waste cooking oil. The calorific value of biodiesel from waste cooking oil is $9,657.591 \mathrm{Cal} / \mathrm{kg}$. The value obtained is in the range of fuel oil values.

\section{Acknowledgements}

The authors would like to thank The Ministry of Research Technology and Higher Education of the Republic of Indonesia who has funded this research with The Excellent Applied Research of University Scheme under the PTUPT-115/SKPP/III/2018 contract number and Laboratory of Unit Operation, Chemical Engineering Department, Universitas Ahmad Dahlan for providing equipment for this research.

\section{References}

[1] Atadashi IM, Sulaiman NMN. The effect of catalysts in biodiesel production: A review. Journal of Industrial and Engineering Chemistry, 2013; 19: 14-26.

[2] Leung DYC, Leung MKH. A review on biodiesel production using catalyzed transesterification. Applied Energy, 2010; 87(4):1083-1095.

[3] Demirbas A. Progress and recent trends in biodiesel fuels. Energy Conversion and Management, 2009; 50(1): 14-34.

[4] Kawentar WA, Budiman. A synthesis of biodiesel from second used cooking oil. Energy Procedia, 2013; 32:190-199.

[5] Heikal EK, Khalil SA, Abdou IK. Biodiesel from jatropha oil. Renewable energy in the Service of Mankind, 2015; $1: 39-46$.

[6] Oliveira JF, Parente Jr. EJS. Biodiesel production from waste coconut oil by esterification with ethanol: The effect of water removal by adsorption. Renewable energy, 2010; 35(11):2581-2584.

[7] Wijaya K. (Desember 2011). Biodiesel dari Minyak Goreng Bekas. [Online]. Available: Information on http://pse.ugm.ac.id/?p=338

[8] Gnanaprakasam A, Sivakumar VM, Surendhar A, Thirumarimurugan M, Kannadasan T. Recent strategy of biodiesel production from waste cooking oil and process influencing parameters: a review. Journal of Energy. 2013; 213: 1-10.

[9] Ruhyat N, Firdaus A. Analisis Pemilihan Bahan Baku Biodiesel di DKI Jakarta. Thesis, Universitas Mercu Buana, Jakarta; 2006.

[10] Zhang Y, Du MA, McLean DD, Kates M. Biodiesel production from waste cooking oil: 1. Process design and technological assessment. Journal of Bioresource Technology, 2003; 89(1):1-16.

[11] Tran HL, Ryu YJ, Seong DH, Lim SM, Lee CG. An effective acid catalyst for biodiesel production from impure raw feedstocks. Biotechnology and Bioprocess Engineering, 2013; 18 (2): 242-247.

[12] Ehsan Md, Chowdury MdTH. Production of biodiesel using alkaline based catalysts from waste cooking oil: A case study. Procedia Engineering, 2015; 105:638-645.

[13] Guldhe A, Bux F. Advances in synthesis of biodiesel via enzyme catalysis: novel and sustainable approaches. Renewable and Sustainable Energy Reviews, 2015; 41:1447-1464.

[14] Taufiqurrahmi N, Mohamed AR, Bhatia S. Production of biofuel from waste cooking palm oil using nanocrystallin zeolite as catalyst: process optimization studies. Bioresource Technology, 2011; 102(22): 10686-10694.

[15] Astuti E, Mufrodi Z. Pembuatan biodiesel Dari Minyak Goreng Bekas Proses Kontinyu: Uji Kualitas. In: Proc. of National 
Conference of Chemical Industry and Natural Resources, Mataram; 2017.

[16] Swern D. Bailey's Industrial Oil and Fat Product, 2, 4 ed., pp 130-133, John Wiley and Sons, New York, 1982.

[17] Siswani ES, Kristianingrum S, Suwardi. Sintesis dan Karakterisasi Biodiesel dari Minyak Jelantah pada Berbagai Waktu dan Suhu. Prosiding Seminar Nasional Penelitian, Pendidikan dan Penerapan MIPA (Proceeding of National Conference of Science Education and Application), Universitas Negeri Yogyakarta (2012).

[18] Mufrodi Z, Rochmadi, Sutijan, Budiman. Synthesis acetylation of glycerol using batch reactor and continuous reactive distillation column. Engineering Journal, 2014; 18(2):29-39.

[19] Cahyono RB, Mufrodi Z, Hidayat A, Budiman A. Acetylation of glycerol for triacetin production using zr-natural zeolite catalyst. ARPN Journal of Engineering and Applied Sciences; 11(8):5194-5197.

[20] Astuti E, Supranto, Rochmadi, Prasetya A. Kinetic modeling of nitration of glycerol: three controlling reactions model. Engineering Journal, 2014; 18( 3):73-82.

[21] Astuti E, Supranto, Rochmadi, Prasetya A. Optimum operating conditions of glycerol nitration to produce 1, 3dinitroglycerin. ARPN Journal of Engineering and Applied Sciences, 2016; 11(8):5203 - 5208. 